\title{
Seedling Growth of Cassia tora, Cassia occidentalis and Cassia sophera in Relation to Salinity and pH
}

\author{
Sabiha Sultana and A.K.M. Nazrul Islam \\ Ecology and Environment Laboratory, Department of Botany, University of Dhaka, Dhaka 1000, Bangladesh
}

\begin{abstract}
The paper aimed to investigate the growth of seedlings of three species of Cassia (C. tora, C. sophera and C. occidentalis) at different concentrations of salinity $(\mathrm{NaCl})$ and $\mathrm{pH}$ treatments. All the species showed the highest seedling length under control condition, and with the increase of salinity, C. occidentalis showed the highest sensitivity. The seedling length of $C$. tora at $0.05 \mathrm{M}$ $\mathrm{NaCl}$ significantly $(P=0.05)$ decreased to $5.71 \mathrm{~cm}$, and further increase of salinity to $0.1 \mathrm{M}$, the seedling length was decreased to less than the value of $0.05 \mathrm{M} \mathrm{NaCl}$ treatment and one-third $(2.15 \mathrm{~cm})$ of that of control $(6.92 \mathrm{~cm})$. Seeds of all the species failed to germinate at $0.5 \mathrm{M} \mathrm{NaCl}$. Scarified seeds of $C$. sophera and $C$. occidentalis increased seedling length. The highest seedling length was in $C$. sophera, followed by $C$. tora and $C$. occidentalis. All the species showed significant decrease $(P<0.05)$ of fresh weight with the increase of salinity; scarification of seeds in $C$. occidentalis and $C$. sophera showed higher fresh weight than those of without scarification. Experiments at different $\mathrm{pH}$ levels did not show any significant $(P=0.05)$ change in seedling length, except $C$. sophera, while at acidic $\mathrm{pH}$, both seedling length and dry weight were significantly $(P<0.05)$ decreased.
\end{abstract}

Key words: Cassia spp., seedling growth, salinity, pH.

\section{Introduction}

Salinisation of soil is common in arid and semiarid regions, where the amount of rainfall is insufficient for substantial leaching. High concentrations of salts have detrimental effects on plant growth [1-3]. Plant species differ in their sensitivity or tolerance to salts [4]. There is evidence that organs, tissues and cells at different developmental stages of plants exhibit varying degrees of tolerance to environmental conditions [5]. It is reported that soil salinity suppresses shoot growth more than the root growth [3, $6,7]$. An understanding of growth and survival of plants under saline conditions is needed for screening the plant species for the afforestation in saline deserts and realizing the mechanism that plants use in the avoidance and/or tolerance of salt stress.

In nature, the three species of Cassia (C. tora, $C$. occidentalis and $C$. sophera) appear differently to edaphic features, climatic factors and their seasonal

Corresponding author: A.K.M. Nazrul Islam, Ph.D., research fields: ecology and environment. variation and availability of water. The influence of salinity on germination response was studied in halophytes and non-halophytes (glycophytes) by Rozema [8]. However, inhibition of germination by salt could play a decisive role in limiting geographical distribution of a species and determining their position in the vegetation [9]. Toxic effects of certain ions on seed germination and seedling development had been studied by a number of investigators at the beginning of the century. Stewart [10] and Harris and Pittman [11] found that chloride salts were the most toxic for germination, sulphate less so and carbonate the least. A similar concentration between the ability to germinate under saline conditions and zonation of plants in salt marsh was also reported by Ungar [12]. Seeds of Limonium vulgare Mill. and Limonium humile Mill. slowly germinated in sea water. Most of the seeds, which did not germinate in such a medium, rapidly germinated after being transferred to fresh water [13]. The same was true for Puccinellia nuttalliana [14]. Gale et al. [15] showed that the optimal concentration of sodium chloride in the 
culture solution for growth of Atriplex halimus was a function of environmental conditions. The present investigation was an attempt to study the seedling growth of three Cassia spp. (C. tora, C. occidentalis and $C$. sophera) in relation to salinity and $\mathrm{pH}$.

\section{Materials and Methods}

Seeds of three Cassia species (C. tora, C. occidentalis and $C$. sophera) were germinated with different concentrations of $\mathrm{NaCl}$ solution $(0.05,0.1$, 0.2 and $0.5 \mathrm{M}$ ) and with various $\mathrm{pH}$ conditions to see the effect on seedling growth. Twenty-five healthy seeds of each species were placed on moistened filter papers in Petri dishes for each $\mathrm{NaCl}$ and $\mathrm{pH}$ treatments; four replications were done and the seeds in Petri dishes were moistened daily (approximately 2 $\mathrm{mL}$ ) with the specific $\mathrm{NaCl}$ and $\mathrm{pH}$ solution. After, germination seedlings were allowed to grow in the Petri dishes for $7 \mathrm{~d}$. A control with 25 healthy seeds was also done simultaneously.

After $7 \mathrm{~d}$ of growth, five seedlings of each species were harvested from each Petri dish. The length of root, shoot and fresh weight of each seedling were taken, then dried in the oven at $80^{\circ} \mathrm{C}$ for $24 \mathrm{~h}$ and dry weight was then recorded.

\section{Results}

\subsection{Seedling Growth}

The growth of seedlings of all three species was the best at control, followed by $0.05 \mathrm{M}$ and $0.1 \mathrm{M}$. This suggested that the growth of seedlings was prevented at high levels of $\mathrm{NaCl}$ salinity (Fig. 1 and Table 1).

The highest seedling length of $C$. tora was $6.92 \mathrm{~cm}$ in control, and with the increase of salinity to $0.05 \mathrm{M}$, the seedling length was decreased to $5.71 \mathrm{~cm}$. Further increase of salinity to $0.1 \mathrm{M}$, the length of the seedling became less than half of $0.05 \mathrm{M}$ treatment and one-third to that of control. At $0.2 \mathrm{M}$, the seedling length was the lowest $(1.66 \mathrm{~cm})$, and at $0.5 \mathrm{M}$, seeds did not germinate (Fig. 2).

Seeds of $C$. occidentalis also showed the highest seedling length $7.57 \mathrm{~cm}$ in control (with scarification) and $4.2 \mathrm{~cm}$ (without scarification). The seedling length decreased to $5.07 \mathrm{~cm}$ and $3.90 \mathrm{~cm}$ at $0.05 \mathrm{M}$ $\mathrm{NaCl}$ with and without scarification, respectively. At $0.1 \mathrm{M} \mathrm{NaCl}$, the seedling length was $3.75 \mathrm{~cm}$ and 2.93 $\mathrm{cm}$ with and without scarification, respectively; the length was $1.95 \mathrm{~cm}$ at $0.2 \mathrm{M}$ with scarification (Fig. 2).

C. sophera also showed the highest length of seedlings $(7.74 \mathrm{~cm}$ and $7.28 \mathrm{~cm}$ with and without scarification, respectively) in control. At $0.1 \mathrm{M}$, the seedling length was $6.49 \mathrm{~cm}$ and $3.18 \mathrm{~cm}$ with and without scarification, respectively. These two species did not show any growth at $0.5 \mathrm{M} \mathrm{NaCl}$ without scarification (Fig. 2). The seedling length of $C$. sophera at different $\mathrm{NaCl}$ concentrations is higher than $C$. occidentalis. The results show that both $C$. occidentalis and $C$. sophera are sensitive to salinity and suggest the reason for absence of these two species from the coastal habitat. Seedling length of $C$. tora with various $\mathrm{pH}$ treatments did not show any significant difference; but seedling length of both $C$. occidentalis and C. sophera at $\mathrm{pH} 4$ was significantly lower $(P<0.05)$ than those grown in $\mathrm{pH} 6$ and $\mathrm{pH} 8$ (Fig. 3 and Table 2).

\subsection{Fresh Weight and Dry Weight of the Seedlings}

All three species of Cassia were sensitive to salinity treatment, and showed decrease of fresh and dry weights as the salinity levels were increased. There was a significant decrease $(P<0.05)$ of all the measurements (Table 1) when concentration of $\mathrm{NaCl}$ was increased from $0.05 \mathrm{M}$ to $0.1 \mathrm{M}$ condition. Both C. tora and C. occidentalis exhibited the highest fresh and dry weight at control, i.e., $0.47 \mathrm{~g}(\mathrm{FW})$ and 0.037 g (DW), $0.48 \mathrm{~g}$ (FW) and $0.042 \mathrm{~g}$ (DW) with scarification and $0.437 \mathrm{~g}$ (FW) and $0.037 \mathrm{~g}$ (DW) without scarification, respectively.

Both species showed drastic reduction of fresh weight and dry weight at $0.2 \mathrm{M}$ salinity treatment. The scarified seeds of $C$. sophera and C. occidentalis always 


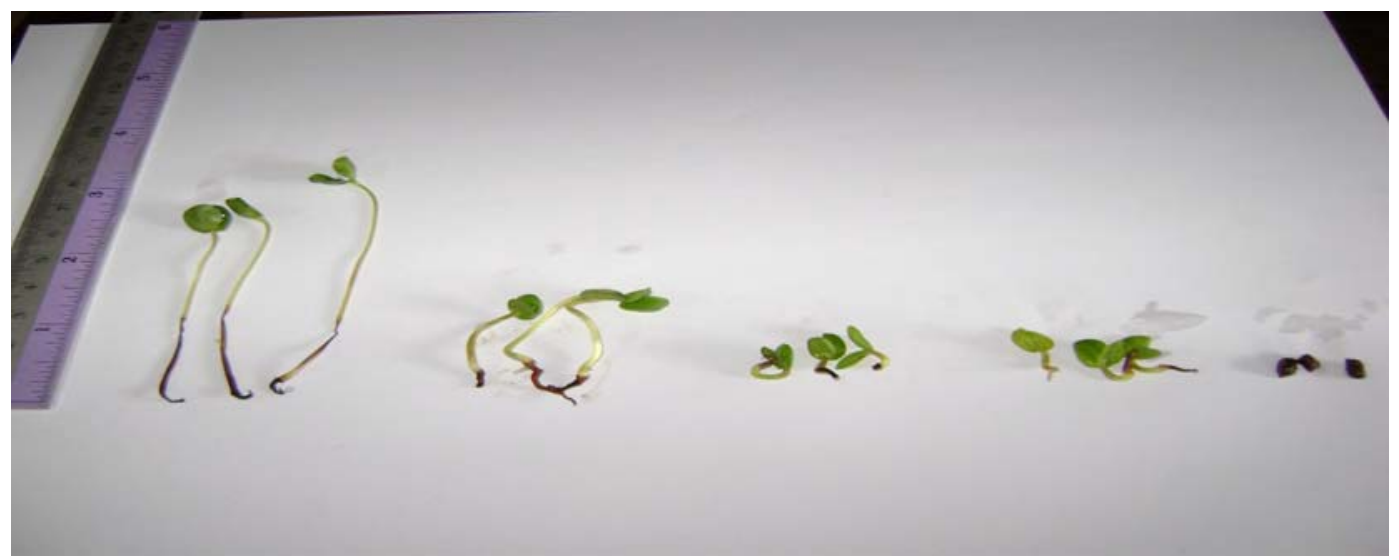

(a)

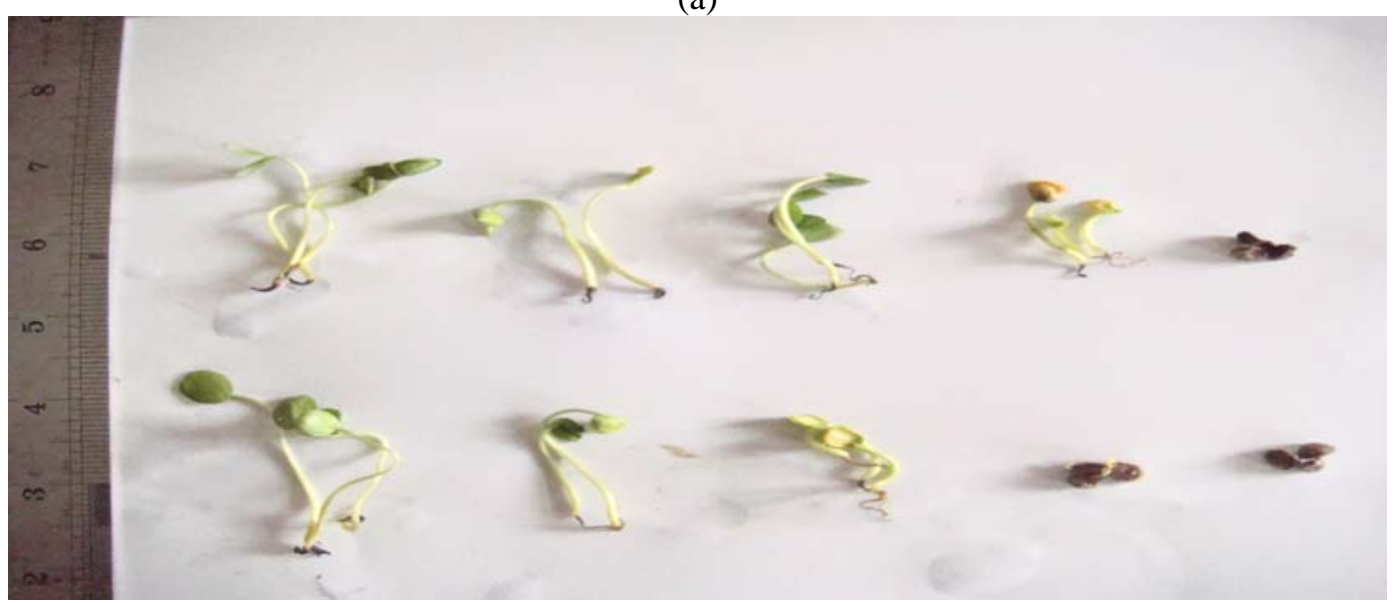

(b)

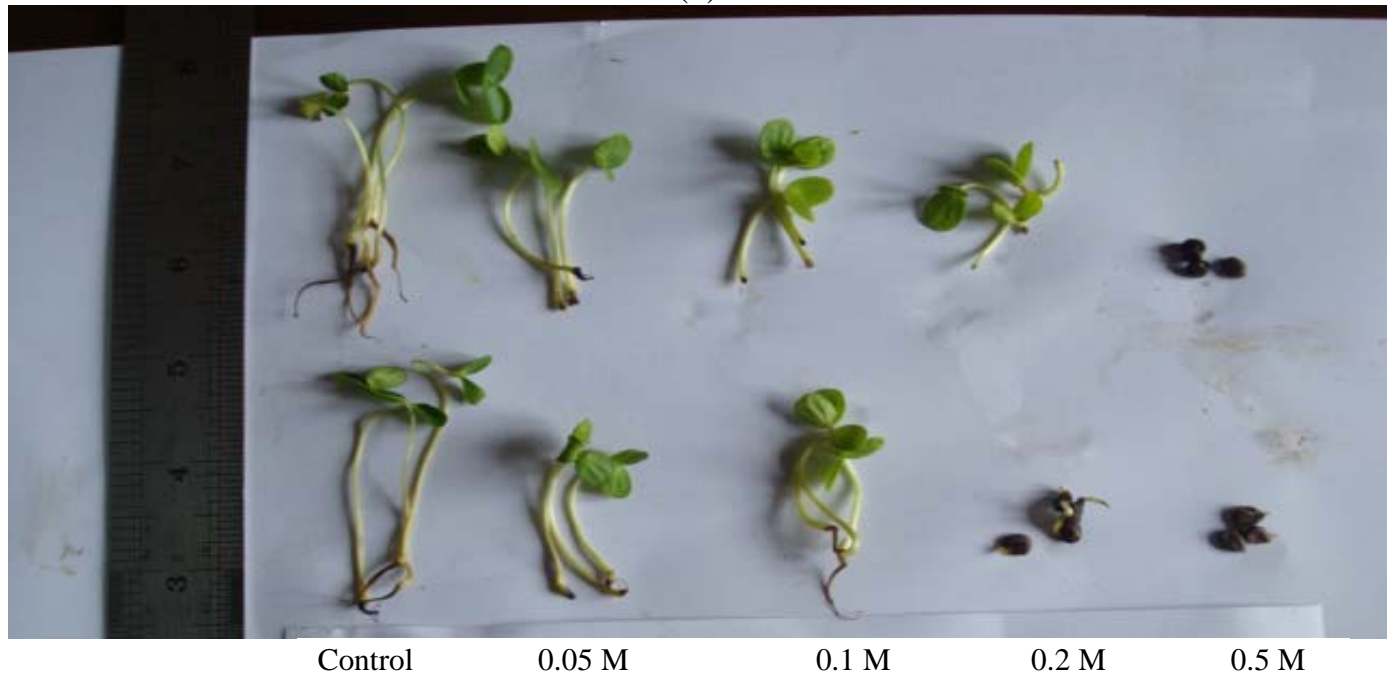

(c)

Fig. 1 Seedlings of Cassia spp. in different salinity treatments.

a: C. tora; b: C. sophera; c: C. occidentalis. Seedlings in the upper row are C. sophera and C. occidentalis scarified, respectively.

showed high values from the seedlings of three species of Cassia (C. tora, C. occidentalis and C. non-scarified seeds. Delay in germination in non-scarified seeds possibly decreased the growth. All sophera) exhibited highest fresh and dry weight at control. 


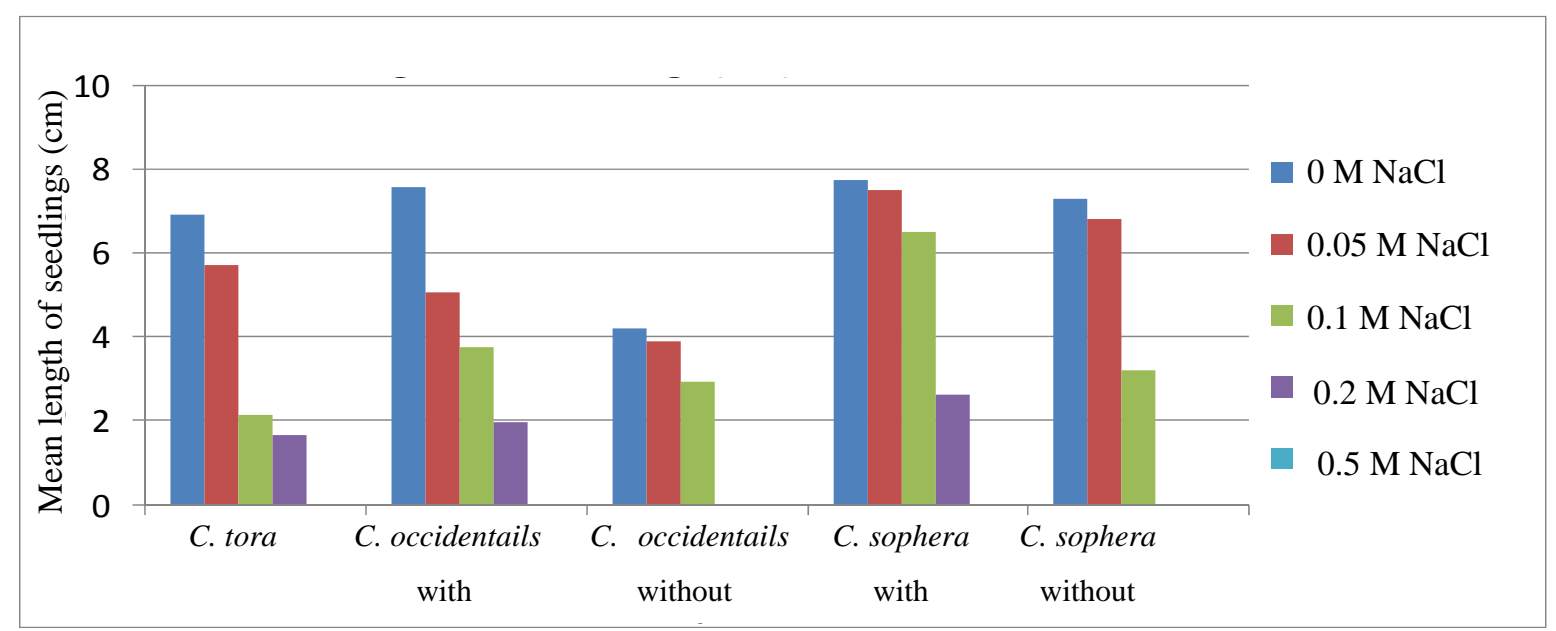

Fig. 2 Mean length $(\mathrm{cm})$ of $C$. tora, C. occidentails and C. sophera at different NaCl treatments with and without scarification.

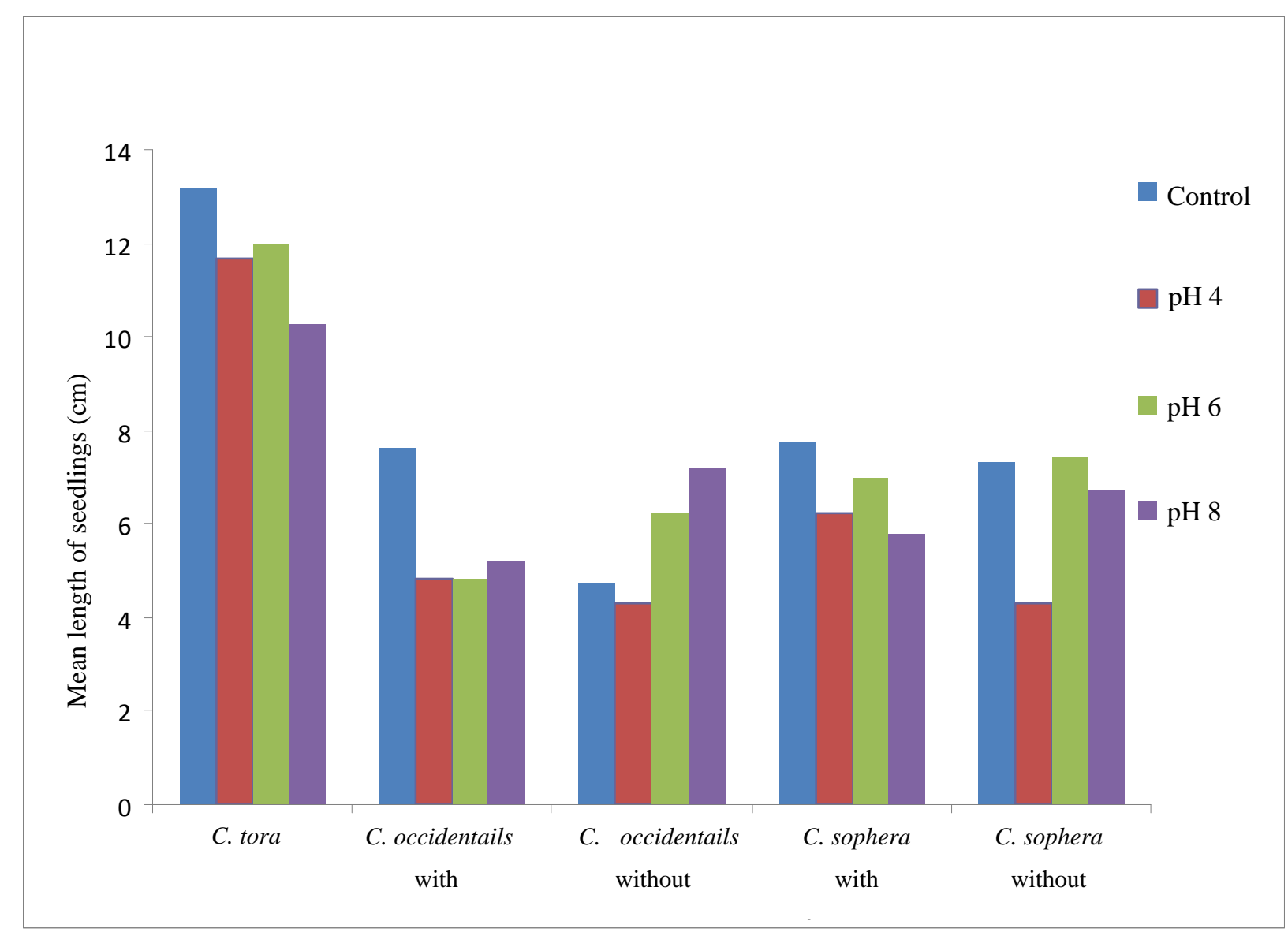

Fig. 3 Mean length $(\mathrm{cm})$ of $C$. tora, $C$. occidentails and $C$. sophera seedling at different pH treatments with and without scarification.

Total dry weight of $C$. tora was unaffected by $\mathrm{pH}$ treatments. However, significant decrease $(P<0.05)$ of dry weight was observed both in $C$. occidentalis and C. sophera at $\mathrm{pH} 6$ and $\mathrm{pH} 8$ (Table 2). Dry weight/fresh weight in scarified seeds of $C$. occidentalis (except grown at $\mathrm{pH}$ 8) and C. sophera was higher than those grown without scarification (Table 2). 
Table 1 Fresh and dry weight (g) of C. tora, C. occidentails and C. sophera at different salinity (NaCl) treatments.

\begin{tabular}{lllll}
\hline Plant species & Treatment & Fresh weight $(\mathrm{g})$ & Total dry weight $(\mathrm{g})$ & Fresh weight/dry weight \\
\hline & 0 & $0.470 \pm 0.024$ & $0.037 \pm 0.008$ & 12.702 \\
C. tora & 0.05 & $0.410 \pm 0.595$ & $0.035 \pm 0.089$ & 11.714 \\
& 0.1 & $0.290 \pm 0.205$ & $0.032 \pm 0.142$ & 9.062 \\
& 0.2 & $0.250 \pm 0.129$ & $0.031 \pm 0.1591$ & 8.333 \\
& 0.5 & - & - & - \\
\hline & 0 & $0.437 \pm 0.0826$ & $0.037 \pm 0.00817$ & 11.81 \\
C. occidentalis & 0.05 & $(0.481 \pm 0.0459)$ & $(0.042 \pm 0.0079)$ & $(11.42)$ \\
(with and without & & $0.392 \pm 0.0459$ & $0.031 \pm 0.0082$ & 13.06 \\
scarification) & 0.1 & $(0.411 \pm 0.0458)$ & $(0.042 \pm 0.0009)$ & $(10.25)$ \\
& 0.2 & $0.305 \pm 0.0716$ & $0.025 \pm 0.0226$ & 12.20 \\
& 0.5 & $(0.361 \pm 0.0288)$ & $(0.032 \pm 0.0093)$ & $(11.25)$ \\
& $(0.212)$ & $(0.012)$ & $(17.66)$ \\
& 0 & - & - & - \\
& & $0.317 \pm 0.061$ & $0.025 \pm 0.00091$ & 12.68 \\
C. sophera & 0.05 & $(0.357 \pm 0.039)$ & $(0.035 \pm 0.00091)$ & $(10.20)$ \\
(with and without & & $0.300 \pm 0.038$ & $0.025 \pm 0.00091$ & 12.00 \\
scarification) & 0.1 & $(0.395 \pm 0.020)$ & $(0.033 \pm 0.00079)$ & $(12.15)$ \\
& 0.2 & $0.105 \pm 0.040$ & $0.015 \pm 0.00091$ & 7.00 \\
& 0.5 & $(0.352 \pm 0.064)$ & $(0.033 \pm 0.00079)$ & $(10.83)$ \\
& $(0.167 \pm 0.032)$ & $(0.012 \pm 0.00079)$ & $(13.91)$ \\
\end{tabular}

Each value is the mean of four replicates and each replicate is the mean of five seedlings. Values in parenthesis are the result with scarified seeds. 95\% confidence limits are given. -: means no growth.

Table 2 Mean seedling length, fresh and dry weight (g) of C. tora, $C$. occidentails and $C$. sophera at different pH treatments.

\begin{tabular}{llllll}
\hline Plant species & $\begin{array}{l}\text { Treatment } \\
\mathrm{pH}\end{array}$ & $\begin{array}{l}\text { Length } \\
(\mathrm{cm})\end{array}$ & Fresh weight $(\mathrm{g})$ & Total dry weight $(\mathrm{g})$ & Fresh weight/dry weight \\
\hline & 4 & $11.96 \pm 0.48$ & $0.425 \pm 0.036$ & $0.025 \pm 0.00684$ & 17.00 \\
C. tora & 6 & $12.00 \pm 0.48$ & $0.467 \pm 0.059$ & $0.028 \pm 0.0059$ & 16.98 \\
& 8 & $10.25 \pm 1.84$ & $0.420 \pm 0.049$ & $0.025 \pm 0.0068$ & 16.80 \\
\hline & 4 & $4.31 \pm 0.66$ & $0.250 \pm 0.059$ & $0.025 \pm 0.0091$ & 10.00 \\
& & $(4.84 \pm 1.44)$ & $(0.170 \pm 0.009)$ & $(0.015 \pm 0.0092)$ & $(11.33)$ \\
$\begin{array}{l}\text { C. occidentalis } \\
\text { (with and without }\end{array}$ & 6 & $6.24 \pm 0.26$ & $0.232 \pm 0.038$ & $0.0175 \pm 0.0079$ & 13.25 \\
scarification) & & $(5.24 \pm 0.43)$ & $(0.220 \pm 0.025)$ & $(0.010 \pm 0.000)$ & $(22.00)$ \\
& 8 & $7.185 \pm 1.79$ & $0.230 \pm 0.060$ & $0.012 \pm 0.0075$ & 19.16 \\
& $(4.83 \pm 1.65)$ & $(0.210 \pm 0.065)$ & $(0.018 \pm 0.0079)$ & $(12.00)$ \\
\hline & 4 & $4.30 \pm 0.39$ & $0.230 \pm 0.950$ & $0.030 \pm 0.0076$ & 7.60 \\
C. sophera & & $(6.23 \pm 0.31)$ & $(0.327 \pm 0.030)$ & $(0.027 \pm 0.0079)$ & $(12.11)$ \\
(with and without & 6 & $7.42 \pm 1.65$ & $0.210 \pm 0.030$ & $0.022 \pm 0.0079$ & 9.54 \\
scarification) & & $(5.81 \pm 0.86)$ & $(0.275 \pm 0.062)$ & $(0.025 \pm 0.0092)$ & $(11.00)$ \\
& 8 & $6.70 \pm 1.64$ & $0.220 \pm 0.008$ & $0.020 \pm 0.000$ & 11.00 \\
& & $(7.00 \pm 0.48)$ & $(0.330 \pm 0.190)$ & $(0.025 \pm 0.0066)$ & $(13.20)$ \\
\hline
\end{tabular}

Values in parenthesis are with scarification. 95\% confidence limits are given.

\section{Discussion}

Salinity is a major form of land degradation worldwide [16]. Growth of plants on salt-affected soils may be restricted by salinity (high concentrations of soluble salts).

Greenway [17] in his experiments with Hordium vulgarae exposed to salinity treatments showed the results of leaf growth, shoot and roots separately. In general, $\mathrm{NaCl}$ treatment decreased the development of leaves. He has also shown that the uptake of sodium by the leaves was the main factor for the decrease of growth.

It was found that $C$. occidentalis and $C$. sophera are more sensitive to $\mathrm{NaCl}$ treatment than $C$. tora, and 
growth of seedlings is retarded with the increase of $\mathrm{NaCl}$ concentration. Reduction of plant growth and dry matter accumulation in Phaseolus vulgaris under saline condition was also reported in Refs. [3, 18]. An eco-physiological investigation into the salt tolerance of Glaux maritima L. was carried out by Rozema [8] and found that high salt concentration significantly decreased fresh and dry weight production. Wheat cultivars (Triticum aestivum L. cv. Inia 66 and cv. Sonalika) were found to grow well at low salinity levels [19]. Nazrul Islam and Sabiha [20] in the earlier investigation have shown that increasing salinity has a decreasing effect on germination for all three Cassia spp..

Optimal shoot growth of Aster tripholium occurred when plants were in a salt solution, whereas, roots grew the best in fresh water [21]. Increase in root growth and decrease of shoot growth were obtained under high water stress induced by $\mathrm{NaCl}$, whereas, total growth of the plants was reduced [22, 23]. Shoot growth of Aster tripholium was the best at $1 \% \mathrm{NaCl}$ [24]. In Atiplex polycarpa, salinity inhibited shoot growth more than the root growth [25].

Length of Cassia seedling showed a significant ( $P$ $<0.05$ ) reduction with the increase of salinity from $0.05 \mathrm{M}$ onwards, suggesting that seedling growth of Cassia spp. is not detrimental at low salinity level. Death of fine roots of Poncirus trifoliate in response to increased $\mathrm{NaCl}$ was observed by Tozlu et al. [26], and they designated this mechanism as "fine root turnover" which was also noted in the present investigation with Cassia spp..

Response of the three Cassia spp. in relation to $\mathrm{pH}$ treatments did not show any significant difference. It suggested that the species can grow and establish in soils of wide range of $\mathrm{pH}$ conditions.

\section{Conclusions}

All the three Cassia spp. were sensitive to salinity. C. tora showed tolerance at the lowest salinity level and suggested that this species can survive, grow and establish in the coastal areas of low saline condition. Low population of $C$. sophera and $C$. occidentalis in the natural environment is due to their poor germination. C. tora will grow both in acid and alkaline soils. C. sophera and C. occidentalis will face difficulty to grow and survive in alkaline soils.

\section{References}

[1] Bernstein, L. 1962. "Salt Affected Soils and Plants." In Proceedings of the Paris Symposium: Arid Zone Research. Vol. 18. Paris: UNESCO: 139-74.

[2] Taiz, L., and Zeiger, E. 2006. Plant Physiology, 4th ed.. Sunderland, USA: Sinauer Associates Inc., Publishers, 764.

[3] Ramoliya, P. J., Patel, H. M., and Pandey, A. N. 2004. "Effect of Salinization of Soil on Growth and Macro- and Micro-Nutrient Accumulation in Seedlings of Acacia catechu (Mimosaceae)." Annals of Applied Biology 144 (3): 321-32.

[4] Marschner, H. 1995. Mineral Nutrition of Higher Plants. London: Academic Press, 889.

[5] Munns, R. 1993. "Physiological Processes Limiting Plant Growth in Saline Soils: Some Dogmas and Hypotheses.” Plant Cell and Environment 16: 15-24.

[6] Maas, E. V., and Hoffman, G. J. 1977. "Crop Salt Tolerance-Current Assessment.” Journal of Irrigation and Drainage Division 103 (2): 115-34.

[7] Munns, R. 2002. "Comparative Physiology of Salt and Water Stress.” Plant Cell and Environment 25: 239-50.

[8] Rozema, J. 1975. "The Influence of Salinity, Inundation and Temperature on the Germination of Halophytes and Non-halophytes.” Oecol Plant 10: 341-53.

[9] Waisel, Y., and Pollak, G. 1969. "Estimation of Water Stresses in the Active Root Zone of Some Native Halophytes in Israel.” J. Ecol. 57: 789-94.

[10] Stewart, J. 1898. Effect of Alkali on Seed Germination. The 9th Annual Report, Utah Agriculture Experimental Station.

[11] Harris, F. S., and Pittman, D. W. 1918. "Soil Factors Affecting the Toxicity of Alkali.” J. Agr. Res. 15: 287-319.

[12] Ungar, I. A. 1967. "Influence of Salinity and Temperature on Seed Germination.” Ohio J. Sci. 67 (2): 120-3.

[13] Boorman, L. A. 1968. "Some Aspects of the Reproductive Biology of Limonium vulgare Mill. and Limonium humile Mill..” Annals of Botany 32 (128): 803-24.

[14] Mack, A. J., and Ungar, I. A. 1971. "The Effect of Salinity on Germination and Early Growth of Puccinellia nuttalliana.” Can. J. Bot. 49 (4): 515-20. 
[15] Gale, J., Naaman, R., and Poljakoff-Mayber, A. 1970. "Growth of Atriplex halimus in Sodium Chloride Salinated Culture Solutions as Affected by the Relative Humidity of the Air.” Austr. J. Biol. Sci. 23 (4): 947-52.

[16] Dudal, R., and Purnel, M. F. 1986. "Land Resources: Salt Affected Soils.” Reclamation and Revegetation Research 5 (1): 1-10.

[17] Greenway, H. 1963. "Plant Response to Saline Substrate II: Chloride, Sodium and Potassium Uptake and Translocation in Young Plants of Hordium vulgare during and after Sodium Treatment.” Austr. J. Bio. Sci. 15 (1): 39-57.

[18] Delgado, M. J., Ligero, F., and Liuch, C. 1994. "Effects of Salt Stress on Growth and Nitrogen Fixation by Pea, Faba-Bean, Common Bean and Soybean Plants.” Soil Biology and Biochemistry 26 (3): 371-6.

[19] Nazrul Islam, A. K. M. 1989. "Water Relation of Two Cultivars of Wheat in Relation to Salinity.” Bangladesh $J$. Bot. 16 (2): 225-7.

[20] Nazrul Islam, A. K. M., and Sultana, S. 2011. "Comparative Eco-physiology of Cassia tora L., C. occidentalis L. and C. sophera L. Part I: Germination Ecology in Relation to Environmental Factors.” Physiol. Ecol. and Environ. Sci. 2: 51-8.
[21] Montfort, C., and Brandrup, W. 1928. "Physiologische und Pflanzengeographische Seesalzwirkungen III: Vergleichende Untersuchungen der Salzwachstumsreation von Wujzeln.” Jahrb. Wiss. Bot. 67: 105-73.

[22] Stocker, O. 1960. "Physiological and Morphological Changes in Plant Due to Water Deficiency.” In Plant-Water Relationship in Arid and Semi Arid Conditions. Paris: UNESCO de Fontenory, 63-104.

[23] Troughton, A. 1963. "A Comparison of Five Varieties of Lolium perenne with Special Reference to the Relationship between the Root and Shoot System.” Euphytica 12 (1): 49-56.

[24] Bickenback, K. 1932. "Zur Anatomie und Physiologie Einiger Strand und Dunenpflanzen: Beitrage zum Halophyten Problem.” Beitr. Biol. Pflanz. 19: 334-70.

[25] Chatterton, N. J., and Mckell, C. M. 1969. "Atriplex polycarpa I: Germination and Growth as Affected by Sodium Chloride in Water Cultures.” Agron. J. 61 (3): 448-50.

[26] Tozlu, I., Moore, G. A., and Guy, C. L. 2000. "Effect of Increasing $\mathrm{NaCl}$ Concentration on Stem Elongation, Dry Mass Production, and Macro- and Micro-nutrient Accumulation in Poncirus trifoliate.” Australian Journal of Plant Physiology 27 (1): 35-42. 